\title{
CLASSIFICATION OF TERRESTRIAL SUBTER- RANEAN FAUNA OF VOLCANIC SUBSTRATES IN THE CANARY ISLANDS
}

\author{
Josè L. MARTÍN, Helga GARCÍA, Y P. OROMÍ*
}

\section{SUMMARY}

A system is proposed for classifying the species occurring in the hypogean environment in relation to their ecological and evolutionary characteristics. The ecological criteria utilized relate to the preferred habitat of the animals (the epigean, endogean or hypogean environment) and the evolutionary criteria specify the grade of adaptive modification in three characteristics: reduction of eyes, amount of pigmentation and extent of elongation of the appendages. The object of developing this classification is to provide a system appropriate for those regions such as those with volcanic rocks - in which the cave faunas include elements originating in different environments, and in which the species show very variable adaptive grades, depending primarily on the antiquity of the island or other distinct geological zone, where they are found.

Keywords: cave fauna, Canary islands.

In the time since Schiödte (1849) and Schiner (1854) proposed the first classifications of cavernicolous species, great advances have been made in understanding the habitats and biology of these animals; this has revolutionised a number of old ideas.

The diversity of ecological and morphological types which occur together in caves ensures that their classification is not an easy task; nonetheless, many authors have made the attempt, some proposing new classifications (Schiner, 1854; Dudich, 1932; Chapman, 1986) and others merely trying to improve the previous ones (Barr, 1968; Vandel, 1964). Among the varied existing proposals (Table 1) the one most generally accepted at present is probably that proposed by Schiner (1854) and subsequently modified by Racovitza (1907). This classification divides cavernicolous animals into troglobites, troglophiles and trogloxenes on the basis of behavioural characteristics, although at times these are associated with morphological peculiarities (Holsinger, 1988) and troglobites are specified as being eyeless, depigmented and with long appendages. This approach proves to be unsatisfactory in various ways,

\footnotetext{
* Departamento de Biología Animal, Facultad de Biología Universidad de La Laguna Tenerife, Canary Islands, Spain
} 
since there are species which lack the specified morphological characteristics and yet live permanently in caves, so that they should be considered as troglobites. In many cases such a situation permits recognition of a certain gradation in the level of adaptation of troglobites. Examples are provided by several species encountered in young volcanic islands in the Canaries (e.g. El Hierro: Oromí et al., 1991) and in Hawaii (Howarth, 1972), as well as in particular tropical karst areas in Papua New Guinea (Brignoli, 1981) and in Asia and Australasia (Chapman, 1986). Jeannel did not overlook this fact and in his classical work "Les fossiles vivants des cavernes" (1943) he distinguished between recent troglobites and relict troglobites, on the basis of the extent of development of their adaptive characteristics - more marked in the last group.

Table I - Terms for different types of species proposed in different classifications of the subterranean fauna.

\begin{tabular}{|l|l|}
\hline Shadow animals & Schiödte, 1849 \\
\hline Twilight animals & Schiödte, 1849 \\
\hline Animals of dark areas & Schiödte, 1849 \\
\hline Stalactite animals & Schiödte, 1849 \\
\hline Ocasional cave animals & Schiner, 1854; Ginet and Decou, 1977 \\
\hline Troglophiles & Schiner, 1854; Racovitza, 1907; Jeannel, 1943; Hamilton-Smith, 1970 \\
\hline Eutroglophiles & Pavan, 1950 \\
\hline Subtroglophiles & Pavan, 1950 \\
\hline Troglobites & Schiner, 1854; Racovitza, 1907; Jeannel, 1943; Pavan, 1950; \\
& Hamilton-Smith, 1970; Ginet and Decou, 1977 \\
\hline Recent troglobites & Jeannel, 1943 \\
\hline Relict troglobites & Jeannel, 1943 \\
\hline Trogloxenes & Racovitza, 1907; Jeannel, 1943 \\
\hline Eutrogloxenes & Pavan, 1950 \\
\hline Subtrogloxenes & Pavan, 1950 \\
\hline Regular trogloxenes & Hamilton-Smith, 1970; Ginet and Decou, 1977 \\
\hline Irregular trogloxenes & Ginet and decou, 1977 \\
\hline Accidental trogloxenes & Hamilton-Smith, 1970 \\
\hline Phyletic trogloxenes & Pavan, 1950 \\
\hline Aphyletic trogloxenes & Pavan, 1950 \\
\hline Xenocaval animals & Hesse, 1924 \\
\hline Tychocaval animals & Hesse, 1924 \\
\hline Eucaval animals & Hesse, 1924 \\
\hline Pseudotroglobionts & Dudich, 1932 \\
\hline Hemitroglobionts & Dudich, 1932 \\
\hline Eutroglobionts & Dudich, 1932 \\
\hline Edaphobites & Coiffait, 1959 \\
\hline Edaphophiles & Coiffait, 1959; Ginet and Decou, 1977 \\
\hline Edaphoxenes & Coiffait, 1959; Ginet and Decou, 1977 \\
\hline Pholeophiles & Coiffait, 1959 \\
\hline Stytigicoles & Chapman, 1986 \\
\hline Stygoxenes & Chapman, 1986 \\
\hline Parasites & Ginet and Decou, 1977 \\
\hline Guanobites & Ginet and Decou, 1977 \\
\hline Cryptozoic animals & Peck, 1990 \\
\hline & \\
\hline
\end{tabular}


Originally troglobites were defined as inhabitants of caves, with the implication that they lived only inside the caves themselves. But long ago Racovitza (1907) realised that their habitat was really more extensive when he wrote "... j'incline à penser que beaucoup de cavernicoles ont leur habitat normal dans les fentes, et non dans les grottes ...”. Subsequently authors such as Jeannel (1943) and Ginet \& Decou (1977) came to the same conclusion. In any case almost all the specialists implied that terrestrial troglobites occurred only in karst environments (Vandel, 1964), in spite of the fact that since the end of the 1930s terrrestrial troglobites were known from Japanese caves (see Torii, 1960).

Discoveries made in recent decades have influenced current concepts relating to the habitat of troglobites. Studies in the Galapagos (Leleup 1965), Japan (Torii 1960 and Ueno 1960), Hawaii (Howarth 1972) and the Canaries (Español \& Ribes 1983; Hernández, et al. 1986) demonstrated the existence of a multitude of troglobites in volcanic regions, and the investigations of Juberthie and his collaborators at the end of the 1970s (Juberthie, et al. 1980) led to the discovery of new troglobites in continental non-calcareous zones.

Both authors who consider the superficial and deep subsoil as distinct environments and those who consider them as different parts of the same environment, treat the most highly adapted species that live in them as troglobites; this implies an intrinsic contradiction since the word troglobite refers literally to life in caves rather than to life in cracks. Nonetheless, the term troglobite can remain valid as soon as we specify that caves are merely large cracks. If we discard the anthropocentric viewpoint on the concept of a cave and accept that a cave is no more than a crack of large size, for tiny subterranean animals a crack is effectively a cave. Following this reasoning, the term troglobite recovers - at least etymologically - exactly the same meaning which it was given by Schiner in 1854 and remains valid for referring to subterranean species that live in cracks in the underground environment.

Many of the difficulties in applying the traditional classifications universally, result from the "atypical" characteristics of the underground environment of certain regions. This is particularly true in the case of volcanic terrain in tropical and subtropical zones, which differs in significant ways from the karst environment of the temperate zones. Volcanic activity gives rise to caves very close to the surface - where roots can penetrate them and other forms of external energy input can occur - and to a great variety of types of shallow, interconnected, underground environments which considerably broaden and diversify the habitat of the troglobites (Oromí et al., 1986). On the other hand in warm and humid climates there is often less difference between conditions above and below ground, with the result that the limits of the epigean and 
hypogean environments are less distinct.

The need for a precise terminology when comparing the faunas of the separate islands of the Canary Archipelago has led us to develop a new classification which, without abandoning the classical one of Schiner-Racovitza, will be more useful for our purpose. In order to avoid mixing up aspects that are not exactly correlated, such as form and habitat, we have developed two systems of classification for the species concerned, defining respectively their evolutionary characteristics (morphology) and their ecological characteristics (habitat).

\section{Ecological classification (habitat) of the species}

In general, species that live on the surface of the soil are called epigean, those that live within it endogean and those that live under it hypogean. But not all the species live exclusively in one of these three environments; they may make use of several of them, although always living primarily in one.

When a species has the majority of its individuals in a particular environment, and furthermore is capable of reproducing and completing the whole of its life cycle there, we say that it is "characteristic" of that environment. We can therefore refer to "epigeobites" and "endogeobites" and "troglobites" as species characteristic respectively of the epigean, endogean and hypogean environments. The terms "epigeobite" and "endogeobite" combine the name of the environment in which the animals live with the termination "-bite"; we have used the term "troglobite" in preference to the perhaps more precise term hypogeobite, because it is more established among biospeleologists and because in reality the hypogean environment constitutes a world of cracks as mentioned above. One can apply similar reasoning with respect to troglophiles and trogloxenes.

Table 2. System of classification of animal species based on their habitats.

\begin{tabular}{ccc}
\hline $\begin{array}{c}\text { Epigean } \\
\text { Environments }\end{array}$ & $\begin{array}{c}\text { Endogean } \\
\text { Environments }\end{array}$ & $\begin{array}{c}\text { Hypogean } \\
\text { Environments }\end{array}$ \\
\hline Epigeobite & Endogeobite & Troglobite \\
Epigeophile & Endogeophile & Troglophile \\
Epigeoxene & Endogeoxene & Trogloxene \\
\hline
\end{tabular}

By combining the name of a specific environment with the ending "-phile" (which means "lover of") we get new terms which correspond to particular types of 
animals, "epigeophiles" "endogeophiles" and "troglophiles". These have significant populations respectively in epigean, endogean and subterranean environments, in which they can reproduce and complete the whole of their biological cycle, but nonetheless have the majority of their individuals in one of the other two types of environment.

Finally, if we do the same with the termination "-xene" (which means "foreigner"), we get "epigeoxenes", "endogeoxenes" and "trogloxenes", which are animals occurring respectively in the epigean, endogean and subterranean environments, but generally in a casual manner and without being able to complete their whole biological cycle in it. Furthermore the majority of their individuals are never in the environment to which the term refers, but in one of the others. Some authors distinguish between facultative trogloxenes and accidental trogloxenes, depending on the cause of their presence in the hypogean environment (Barr 1968).

Following this classification, a single species can be considered "-bite" in one environment, "-phile" in another and "-xene" in a third. All the combinations between these categories are shown in one of the columns of Table 2, applying the constraints that one takes the categories in order and that a species which is "-bite" in one environment cannot also be "-bite" in another.

When the biological cycle of an arthropod includes stages that take place in different environments its classification can become difficult. In these cases we take as a fundamental basis the habitat of the adult. One can see several relevant examples in the fauna of the Canaries.

For instance, beetles of the family Rhizophagidae can be found in epigean environments, but also in endogean and hypogean ones, provided that the food plant of the larvae is present. Their life cycle has a larval phase in the endogean environment and an adult phase outside, during which the adult reproduces. Their presence in the hypogean environment can be considered accidental, since these are animals which may go underground when attracted by the presence of baited traps. This can be confirmed by the fact that in caves it is very difficult to see living adults, although they are relatively abundant in pitfall traps. It is therefore appropriate to classify this species as an epigeobite-endogeophile-trogloxene.

Another example is provided by Diptera of the family Phoridae, especially in the genus Megaselia, whose larvae normally develop in accumulations of rotting organic material. They are extremely abundant in the endogean environment, although they also appear in epigean and hypogean environments. When the adults emerge they 
move to the surface to reproduce, but they are also able to get down into the subsoil; they do this even where there is soil at the surface if there is an appropriate place for them to lay their eggs. Phorids are relatively frequent in some caves, where they represent an important inward flow of energy. This group of species can thus be considered as epigeobites-endogeophiles-troglophiles.

Some difficulties with the proposed system of classification also arise with animals which spend some stage of their life in litter, such as many sprintails. There are epigeobite, endogeobite and troglobite springtails; the first are almost always on the surface and the last underground, but the endogean species frequently turn up in litter. This happens partly because litter is in some ways an ecotone between surface and soil environments. In fact litter can be considered as the deepest layer of the surface environment, and it supports many species which live there and have nothing to do with the soil; this category includes many isopods, chilopods, thysanurans etc; these animals are therefore epigeobites.

Ants and gastropods are other groups which sometimes penetrate the soil and accidentally occur in caves. They are, however, epigeobites and not endogeobites, since they normally feed and reproduce on the surface.

There are other groups of animals which are not covered by this classification because their lifestyle is not directly linked to one of the environments considered. This is the case with parasites, inhabitants of guano and carrion feeders, whose presence in a particular place depends in the first case on where they find their host, in the second on the existence of an accumulation of guano and in the third on the presence of a corpse.

\section{Evolutionary classification (morphology)}

Along with the terminology based on the particular environments which make up the habitat of a species, it is useful to have available another based on its morphology. Those species that are most highly adapted to subterranean life are normally eyeless, lacking in pigmentation and with long appendages (Barr 1968; Culver 1982; Ginet \& Decou 1977; Vandel 1964); although these are the most common morphological specialisations, one sometimes encounters others such as reduction of wings, special development of certain sense organs and enlarged abdomens etc., for reasons that are not always entirely clear.

Reduction of eyes and pigmentation are seen most commonly and there is no 
doubt that these trends contribute to better adaptation for subterranean life; elongation of the appendages, however, is less common and there is some controversy as to whether it is really characteristic of subterranean forms. It is generally accepted that the most highly adapted species show some allometry in the development of their appendages - especially the antennae - and this is linked to an increase in the number (or size) of the sense organs. Although there is not much relevant literature, arguments have been presented both in favour and against these ideas. Culver (1982) reviewed the subject and concluded that the most parsimonious explanation for the allometric tendency was that various cave populations undergo substantial elongation of their appendages in conditions where energy sources are limited, so that there is strong selection favouring the enhancement of mechanisms for foraging and detecting mates in an environment where food shortage precludes the existence of dense populations (see Culver et al. 1990).

It is clear that not all species with morphological adaptations for subterranean life are modified to the same extent. One can find species which, although they live more or less exclusively underground, show scarcely any loss of pigmentation, reduction of eyes or elongation of appendages. The existence of a variety of adaptive grades has been noted by authors from the time of Jeannel (1943) up to the present (Christiansen 1961; Peck 1973; Martin et al 1989). It is possible that the lack of consensus that adaptive evolution to subterranean life necessarily results in a type of morphology with elongated appendages, results from inappropriate comparisons among troglobites in different grades of specialisation. For example, a troglobite with little modification which lives in a eutrophic tropical cave, may have spent more time in the underground environment than a highly modified troglobite in an oligotrophic cave of the temperate zone (Mitchell 1969). The two examples are not comparable, since food shortage does not apply such strong selection pressure in the first as in the second case. It is thus essential, if one is to determine whether there is really a consistent direction of evolution, to make comparisons in the same region, in the same type of cave and, if possible, using species of the same group (genus).

In an attempt to produce a general evolutionary classification we here consider only three characters (or group of characters): the development of eyes, the extent of pigmentation and the enlargement of appendages. On this basis, following the ideas of Christiansen (1962), we have established the following morphological types:

- Hypogeomorph: eyeless species, strikingly depigmented and with elongated appendages (especially the antennae). 
- Epigeomorph: species with eyes and body pigmentation well developed and appendages normal.

- Endogeomorphs: eyeless species, strikingly depigmented and with short appendages.

- Ambimorph: species intermediate between the epigeomorph type and one of the other two.

The strongest candidates for the hypogeomorph category are troglobites, although occasionally epigean or endogean species conform with one of the requirements for this category. The best candidates for the epigeomorphic category are epigeobites; rarely, endogeobites and troglobites may belong to this morphological category, but the normal situation is that they are hypogeomorphs, ambimorphs or endogeomorphs.

The classification that we propose presents several difficulties, especially because there are epigean species which lack eyes (for instance polydesmid diplopods) or pigmentation (many species which live in dark situations) or whose appendages are elongated even in the absence of any special selective pressure (for example spiders of the family Pholcidae or Heteroptera of the subfamily Emesinae). There are also highly variable species in which pigmentation can be present or absent in different populations, as in the case of the spider Nesticus cellulanus (Clerck) in the Iberian peninsula (Ribera, 1979). There are also species within which the extent of development of eyes ranges from forms in which they are almost entirely lacking to those in which they are fully developed, as happens in the spider Agraecina canariensis Wunderlich in the Canaries (Wunderlich, 1991). The species concerned are usually those which live partly in subterranean environments and partly in dark situations on the surface. Such cases are relatively rare, however, and have little effect on comparison of whole faunas. We are therefore of the opinion that, in spite of the difficulties and imperfection of the proposed classification, its application will help to distinguish general levels of adaptation among subterranean faunas of different volcanic islands.

According to the evolutionary state of each of the three characters analysed (eyes, pigmentation and appendages) it is possible to assign a code to each species (Table 3) made up of a combination of three letters specifying the state of the characters. In this way a hypogeomorph is given a code adl and an ambimorph will have some combination containing at least one letter from the pairs $\mathbf{a} / \mathbf{r}$ (eye development), $\mathbf{d} / \mathbf{m}$ (pigmentation) or $\mathbf{n} / \mathbf{s}$ (length of appendages). 
Table 3. Typical evolutionary states for the characters specified.

\begin{tabular}{ccc}
\hline Eye development & Pigmentation & Length of appendages \\
\hline Absent (a) & Depigmented (d) & Long (l) \\
Reduced (r) & Medium pigmentation (m) & Normal (n) \\
Normal(n) & Pigmented (p) & Short (s) \\
\hline
\end{tabular}

The inferred evolutionary polarity for each character in troglobites and endogeobites is shown in Table 4. It is assumed that in the original epigeomorphic form the appendages were of intermediate size between those of an endogean congener and a hypogean one, the eyes completely developed and functional, and the melanic concentration in the integument high.

Table 4. Evolutionary polarity for the characters "eyes", " pigment" and "apppendages" in two groups of subterranean species

\begin{tabular}{lll}
\hline & Troglobite & Endogeobite \\
\hline Eyes & $\mathrm{n} \rightarrow \mathrm{r} \rightarrow \mathrm{a}$ & $\mathrm{n} \rightarrow \mathrm{r} \rightarrow \mathrm{a}$ \\
Pigment & $\mathrm{p} \rightarrow \mathrm{m} \rightarrow \mathrm{d}$ & $\mathrm{p} \rightarrow \mathrm{m} \rightarrow \mathrm{d}$ \\
Appendages & $\mathrm{n} \rightarrow \mathrm{l}$ & $\mathrm{n} \rightarrow \mathrm{s}$ \\
\hline
\end{tabular}

Combining the ecological and evolutionary classifications and taking polarity into account, we obtain the hypothetical evolutionary pathway presented in Figure 1. A subterranean community of recent origin will consist primarily of species such as accidental and facultative trogloxenes, with little relevant adaptation; as time progresses, the first troglophiles will appear and eventually troglobites. The latter will initially be ambimorphs and over time will become transformed into hypogeomorphs.

The proposed classification is not intended to take the place of traditional ones which are much simpler and more useful when referring to subterranean animals and their general ecological requirements. It could, however, be useful when making comparative analyses between subterranean faunas of distinct areas or regions, and may facilitate understanding of the patterns of evolution and colonisation followed by faunas of particular regions, for instance of the Canary Islands. 


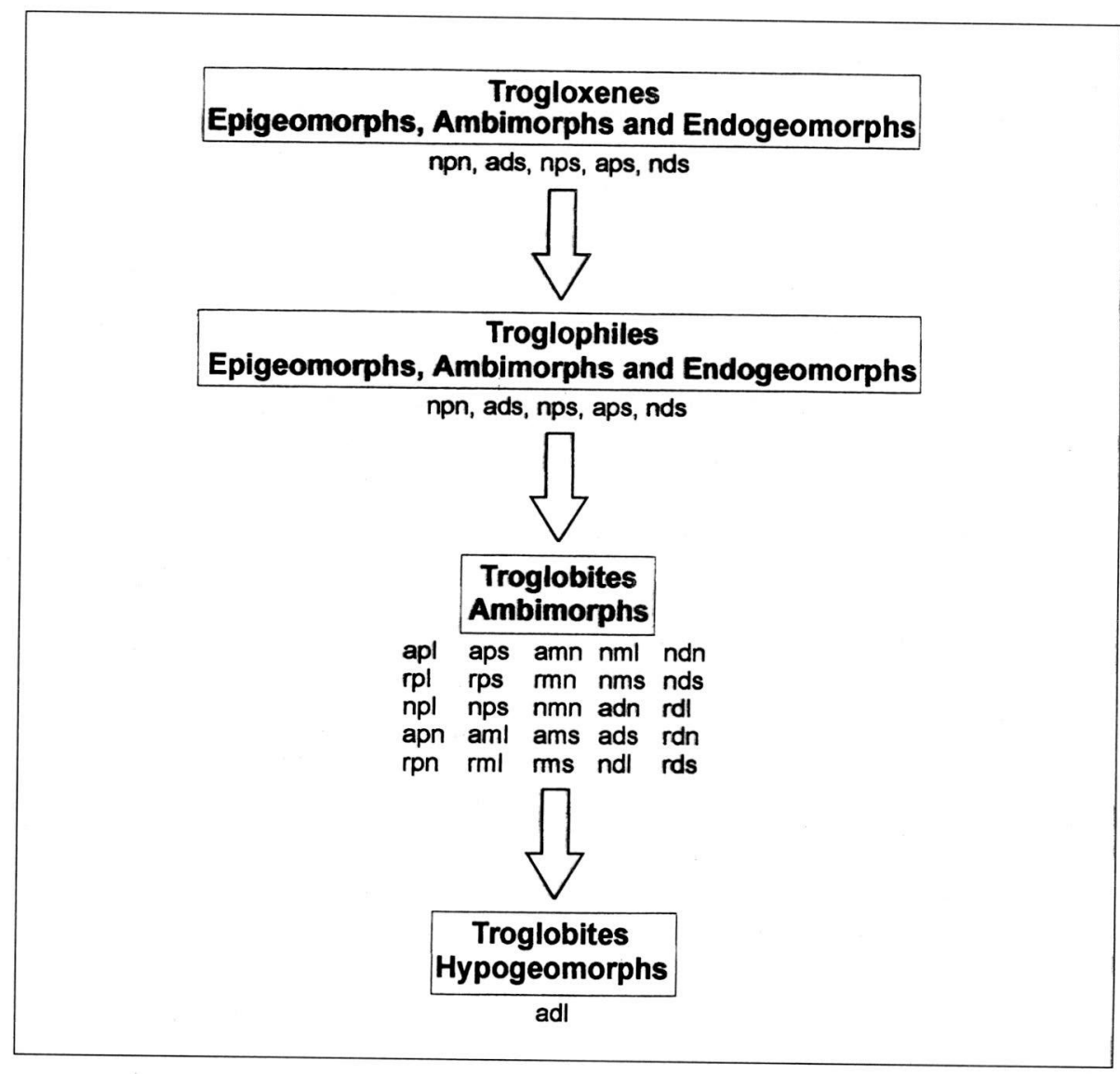

Fig 1. Hypothetical evolutionary sequence for each lineage which colonises the subterranean environment.

\section{Bibliography}

BARR, T.C. 1968. Cave ecology and the evolution of troglobites. Evolutionary Biology, 2: 35102.

BRIGNOLI, P.M. 1981. On some cave spiders from Papua-New Guinea. Proc. $8^{\text {th }}$ International Congress of Speleology, Bowling Green (USA), 1: 110-112.

COIFFAIT, H. 1959. Contribution à la connaissance des Coléoptères du sol. Bull. Lab. Arago, Banyuls-sur-Mer, 7.

CULVER, D. 1982. Cave life. Evolution and ecology. Harvard University Press, Cambridge, Massachusetts and London. 
CULVER, D.C. 1986. Cave faunas, pp- 427-443. In M. Soulé (ed.) Conservation Biology, Sinauer Associates, Inc., Massachusetts.

CULVER, D. C., T. C. KANE and D. W. FONG, R. JONES, M.A. TAYLOR and S.C.

SAUEREISEN.1990. Morfology of cave organisms - is it adaptative?. Mém. Biospéol., 17: 13-26.

CHAPMAN, P. 1986. A proposal to abandon the Schiner-Racovitza clasiffication for animals found in caves. Proc. $9^{\text {th }}$ International Congress of Speleology, Barcelona, 2: 179-182.

CHRISTIANSEN, K.A. 1961. Convergence and parallelism in cave Entomobryinae.Evolution, 15: 288-301.

CHRISTIANSEN, K.A. 1962. Proposition pour la classification des animaux cavernicoles. Spelunca, 2: 75-78.

DUDICH, E. 1932. Biologie der Aggteleker Tropfsteinhöhle Baradla, Ungarn. Speleol. Monographien, 13.

ESPAÑOL, F. and J. RIBES. 1983. Una nueva especie troglobia de Emesinae (Heteroptera, Reduviidae) de las Islas Canarias. Speleon, 26-27: 57-60

GINET, R. and V. DECOU. 1977. Initiation à la biologie et a l'écologie souterraines. Editions universitaires Jean-Pierre Delarge, Paris.

HAMILTON-SMITH, E. 1970. The classification of cavernicoles. Nat. Speleol. Soc. Bull., 33(1): 63-66.

HERNANDEZ, J.J., J.L. MARTIN and A. MEDINA. 1986. La fauna de las cuevas volcánicas de Tenerife (Islas Canarias). Proc. $9^{\text {th }}$ International Congress of Speleology, Barcelona, 2: $139-142$

HESSE, R. 1924. Tiergeographie auf ökologischer Grundlage. Ed. Fischer, Jena

HOLSINGER, J. R. 1988. Troglobites: the evolution of cave-dwelling organisms. American Scientist, 76: 147-153.

HOWARTH, F.G. 1972. Cavernicoles in lava tubes on the islands of Hawaii. Science, 175: 325-326

JEANNEL. R. 1943. Les fossiles vivants des cavernes. Ed. Gallimard, Paris.

JUBERTHIE, CH., B. DELAY y M. BOUILLON, 1980. Extension du milieu souterrain en zone non-calcaire: description d'un nouveau milieu et de son peuplement par les coléoptères troglobies. Mém. Biospéol., 7: 19-52.

LELEUP, N. 1965. Existence d'une faune cryptique relictuelle aux îles Galápagos. Noticias de Galápagos, 5/6: 4-16.

MARTIN, J.L., I. IZQUIERDO y P. OROMI. 1989. Sur les relations entre les troglobies et les espèces épigées des îles Canaries. Mém. Biospéol., 16: 2534.

MITCHELL, R.W. 1969. A comparison of temperate and tropical cave communities. The southwestern Naturalist, 14(1): 73-88.

OROMI, P. J. L. MARTIN, A. L. MEDINA and I. IZQUIERDO. 1991. The evolution of the hypogean fauna in the Canary Islands. In E. C. Dudley (ed.) "The unity of evolutionary biology", Proc. $4^{\text {th }}$ International Congress of Systematic and 
Evolutionary Biology, Maryland, vol. II: 380-395.

OROMI, P., A.L. MEDINA y M.L. TEJEDOR. 1986. On the existence of a superficial underground compartment in the Canary Islands. Proc. $9^{\text {th }}$ International Congress of Speleology, Barcelona, 2: 147-151.

PAVAN, M. 1950. Observations sur les concepts de troglobie, troglophile et trogloxène. Bull. Trim. Assoc. Spéléol. Est. de la Fr., Vesoul, 3(1): 1-4

PECK, S.B. 1973. A review of the invertebrate fauna of volcanic caves in western North America. Bull. Nat. Spel. Soc., 35(4): 99-107.

PECK, S.B. 1990. Eyeless arthropods of the Galapagos Islands, Ecuador: composition and origin of the cryptozoic fauna of a young, tropical, oceanic archipelago. Biotropica, 22(4): 366-381.

RACOVITZA, E. G. 1907. Essai sur les problèmes biospéologiques. Arch. Zool. exp. et gén. Biospelogica I, 4(4): 371-448.

RIBERA, C. 1979. Distribution des Nesticidae cavernicoles de la Péninsule Ibérique. Revue Arachnologique, 2(6): 291-300.

SCHINER, J. R. 1854. Fauna der Adelsberg. Lueger und Magdalener-Grotte. Die Grotten und Höhlen von Adelsberg, Lueg, Planina und Laas. Ed. A. Schmidl, Wien, Braunmüller.

SCHIÖDTE, J. C.1849. Specimen faunae subterraneae. Bidrag til den underjordiske Fauna. Köbenhavn.

TORII, H. 1960. A consideration of the distribution of some troglobionts of japanese caves. (I). Jap. J. Zool. 12: 555-584.

UENO, S.-I. 1960. A new blind Trechid found in a lava cave of Japan. University of Kyoto, Ser. B, 27(1): 49-58

VANDEL, A. 1964. La biologie des animaux cavernicoles. Gauthier-Villars, Paris.

WUNDERLICH, J. 1991. Die Spinnen-Fauna der Makaronesischen Inseln. Taxonomie, Ökologie, Biogeographie und Evolution. Beiträge zur Araneologie, 1. 619 pp. 